\title{
Skeletal Muscles Injury Related to SARS-CoV-2 Infection: A Case Report
}

\author{
Anak Agung Ayu Putri Laksmidewi*, Maria Oktaviany Gabur, Carolin Tiara Lestari Indah \\ Department of Neurology, Faculty of Medicine, Udayana University, Sanglah General Hospital, Denpasar, Bali, Indonesia
}

\begin{abstract}
Edited by: Branislav Filipović Citation: Laksmidewi AAAP, Gabur MO, Indah CTL. A Case Report. Open Access Maced J Med Sci. 2021 Feb 18; 9 (C): $34-39$ Feb 18; 9(C):34-39.
https://doi.org/10.3889/oamjms.2021.5679 Keywords: Neurological manifestation; Skeletal muscle injury; Myalgia, renal damage; SARS-CoV-2; Case report "Correspondence: Anak Agung Ayu Putri Laksmidewi, Department of Neurology, Faculty of Medicine Udayana University, Sanglah General Hospital, Denpasar, Bali, Indonesia. E-mail: putri_laksmidewi@unud.ac.id Received: 07-Jan-202 Accepted: 08-Feb-2021

Copyright: ๑ 2021 Anak Agung Ayu Putri Laksmidewi Maria Oktaviany Gabur, Carolin Tiara Lestari Indah Funding: This research did not receive any financial Competing Interest: The authors have declared that no competing interest exist Open Access: This is an open-access article distributed under the terms of the Creative Commons Attribution

BACKGROUND: Coronavirus disease 2019 (COVID-19) is a disease related to coronavirus (SARS-CoV-2) which is categorized as Nidovirales order, family beta-coronaviridae. Coronavirus infects mainly the lung as well as other organs out of the lung. Extrapulmonary infection includes neurological infection such as the central nervous system, peripheral nervous system, and musculoskeletal with various symptoms. Recent study reported that $30 \%$ of patients had COVID-19-associated skeletal muscle injury.

CASE PRESENTATION: A 78-year-old male with a history of stroke and Type 2 diabetes mellitus came to the emergency department with fever, shortness of breath, decrease of consciousness, joints, and muscles pain. Chest $\mathrm{X}$-ray showed a consolidation in the mid-lower of the lung bilaterally, with prominent bronchovascular markings, polymerase chain reaction COVID-19 result comes out with positive 2 times with 10 days interval. The patient is treated with antibiotics, Avigan, azithromycin, and high-dose intravenous Vitamin C. In the 3rd ward day, the patient still has short of breathiness. However, fever and consciousness improve, but still complaining of pain in the shoulder joint, arm muscles, and knee joint. On the 11th inpatient day, the patient obtains full consciousness: dyspnea improved, no fever, however, the patient still complains of muscle and joint pain. At the end of the inpatient period fever, dyspnea and consciousness seem to be improved; however, the patient still complains of pain in the shoulder joint, arm muscles, and knee joint that not improved with an analgesic. The patient comes back to his home in good condition.
\end{abstract}

CONCLUSION: COVID-19 patients may develop musculoskeletal symptoms such as skeletal injury or myalgia, and this is our first case of COVID-19 infection complicated with skeletal muscle injury.

\section{Introduction}

Coronavirus disease 2019 (COVID-19) is the disease associated with a novel coronavirus strain (SARS-CoV-2) belonging to the Nidovirales order, betacoronaviridae family, a case of which was first reported in 2019 from Wuhan city in China [1]. According to the World Health Organization, there were 35,659,007 confirmed cases and 1,044,269 confirmed deaths due to COVID-19 as of October 7, 2020, and still increasing [2]. Several reports related to COVID-19 indicate extrapulmonary manifestations related to COVID-19 infection. So far, the most common notable early symptoms of the disease are believed to be cough, headache, and fever [3]. However, recently, evidence is emerging on the effect of COVID-19 on the nervous and musculoskeletal systems. The effects of COVID-19 on the nervous and musculoskeletal systems may manifest as anosmia, olfactory function impairment, myalgia, muscle weakness, and Guillain-Barre syndrome [3]. Musculoskeletal symptoms such as fatigue, myalgia, and arthralgia are common symptoms of COVID-19, but their prevalence has not yet been systematically investigated [4].
Until now, it is still being studied about how SARS-CoV-2 invades the central and peripheral nervous system, both in terms of manifestations of symptoms, etiology, and pathogenesis to the therapeutic recommendations that can be given. In an effort to detect COVID-19 cases as early as possible to provide appropriate treatment, every clinician not exclusive to neurologists only must increase awareness in handling cases with neurological symptoms [5].

We report a case of an elderly male presenting with fever, shortness of breath, and myalgia found to be COVID-19 positive, diagnosed with communityacquired pneumonia, and started on high-dose intravenous antibiotics, azithromycin, Avigan, and ascorbic acid.

\section{Case Presentation}

A male patient, 78 years old, Balinese, with a history of stroke, Type-2 diabetes mellitus arrived in the emergency room (ER) of Sanglah Hospital with a decrease in consciousness. The patient was brought by 
the family with a slow decline in consciousness for $3 \mathrm{~h}$ before admission. The patient spoke a little, seemed quite when asked, and family informed that patient just lies in the bed. One week ago, the patient had a fever with temperature measurement of $38.2^{\circ} \mathrm{C}$ and improved with oral paracetamol. In the same time, the patient experienced muscle pain in his shoulder, arm, and knee. A day after the onset of the first symptom, the patient seems tired and lost his appetite. The patient was brought to the clinic, given standard treatment for muscle pain, and was said to be getting better, but soon the fever, joint pain, weakness, and drowsiness appeared. One hour before arriving at the hospital, the patient was restless and talked gibberish. Three hours after admission, after he treated, the patient feels better and able to recognize his children. There is no history of contact with confirmed SARS-CoV-2 case, no record of travelling outside the town; however, he lived in a local transmission area. During the examination in the ER, the patient opened his eyes when called, being able to answer questions, he was disoriented to place and unable to follow the orders. There is no history of hypertension, cardiac problems, and family history related to his complaint. He has five children, unemployed, does not smoke, or drink alcohol. He had not previously received any treatment for this disease.

The clinical findings at emergency department admission. On physical examination, blood pressure was $90 / 60 \mathrm{mmHg}$, pulse rate $117 \times / \mathrm{min}$, respiratory rate 30 times/min, temperature $38.1^{\circ} \mathrm{C}, 80 \% \mathrm{SpO}_{2}$ with Glasgow Coma Scale E3V4M5, and without limbs paresis, there is no abnormality in the central and peripheral nervous system, however, a musculoskeletal sign founded which was muscle and joint pain.

Results of Laboratory tests. Complete blood count showed an increase in leukocyte counts $12,470 / \mu$ l with segmental neutrophil was $11,800 / \mu$ l and segmental

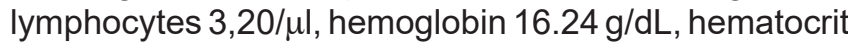
$53.17 \%$ and platelets $99,730 / \mu \mathrm{l}$, procalcitonin $1.21 \mathrm{ng} / \mathrm{ml}$ and C-reactive protein (CRP) $10.45 \mathrm{mg} / \mathrm{dl}$, D-dimer 0.17 , and $\mathrm{Hba1c} 7$. The results of blood chemistry tests showed blood urea nitrogen $99.5 \mathrm{mg} / \mathrm{dl}$, creatinine 2.08, glomerular filtration rate 21.85 , alanine aminotransferase (ALT) $48.9 \mathrm{U} / \mathrm{L}$, aspartate aminotransferase (AST) $37.40 \mathrm{U} / \mathrm{L}$, random blood glucose $203 \mathrm{mg} / \mathrm{dl}$, and albumin $3.1 \mathrm{~g} / \mathrm{dl}$, ferritin $1930.60 \mathrm{ng} / \mathrm{ml}$, natrium 168 $\mathrm{mmol} / \mathrm{L}$, and calcium $3.72 \mathrm{mmol} / \mathrm{L}$. Creatinine kinase test was not available in our facility. Blood gas analysis indicates compensated respiratory alkalosis. The first COVID-19 polymerase chain reaction (PCR) swab test (Figure 1) come out positive and shows the same result

\begin{tabular}{|c|c|c|c|c|c|c|c|c|}
\hline No & $\begin{array}{l}\text { TANGGAL } \\
\text { ORDER }\end{array}$ & $\begin{array}{c}\text { KODE } \\
\text { SPESIMEN }\end{array}$ & $\begin{array}{c}\text { TANGGAL } \\
\text { SAMPEL } \\
\text { DITERIMA }\end{array}$ & $\begin{array}{l}\text { TANGGAL } \\
\text { SAMPEL } \\
\text { DIKERJAKAN }\end{array}$ & $\begin{array}{c}\text { TANGGAL } \\
\text { HASIL }\end{array}$ & ASAL & $\begin{array}{l}\text { JENIS } \\
\text { SPESIMEN }\end{array}$ & HASIL \\
\hline 1 & $\begin{array}{c}26.09 \cdot 2020 \\
06: 44: 45\end{array}$ & 260920/RSUP/384 & $\begin{array}{c}26.09 \cdot 2020 \\
14: 14: 32\end{array}$ & 26.09-2020 14.14:32 & $\begin{array}{c}26 \cdot 09 \cdot 2020 \\
14: 21: 50\end{array}$ & $\begin{array}{l}\text { RSUP } \\
\text { SANGLAA } \\
\text { DENPASAR }\end{array}$ & $\begin{array}{l}\text { Swab } \\
\text { OP/NP }\end{array}$ & $\begin{array}{l}\text { Positif } \\
\text { SARS. } \\
\text { CoV2 }\end{array}$ \\
\hline 2 & $\begin{array}{c}05 \cdot 10 \cdot 2020 \\
00: 03: 44\end{array}$ & 051020/RSUP/020 & $\begin{array}{c}05 \cdot 10 \cdot 2020 \\
13: 38: 48\end{array}$ & $05-10 \cdot 202013: 38: 48$ & \begin{tabular}{|c|}
$05 \cdot 10 \cdot 2020$ \\
$14: 07: 08$
\end{tabular} & $\begin{array}{l}\text { RSUP } \\
\text { SANGLAH } \\
\text { DENPASAR }\end{array}$ & $\begin{array}{l}\text { Swab } \\
\text { NP/OP }\end{array}$ & $\begin{array}{l}\text { Positiff } \\
\text { SARS. } \\
\text { CoV2 }\end{array}$ \\
\hline
\end{tabular}

Figure 1: SARS-CoV-2 polymerase chain reaction swab results after 10 days. Plain chest X-ray (Figure 2) showed consolidation in the mid to lower area of the right and left lung, prominent bronchovascular markings, and aortic knob (+). Based on physical and supporting examination, the patient diagnosed of severe SARSCoV-19, community-acquired pneumonia with Type 1 respiratory failure, septic encephalopathy, COVID-19related myalgia, hyperglycemia, Stage 2 acute kidney injury, and thrombocytopenia. Laboratory test's result during hospitalization is shown in Table 1.

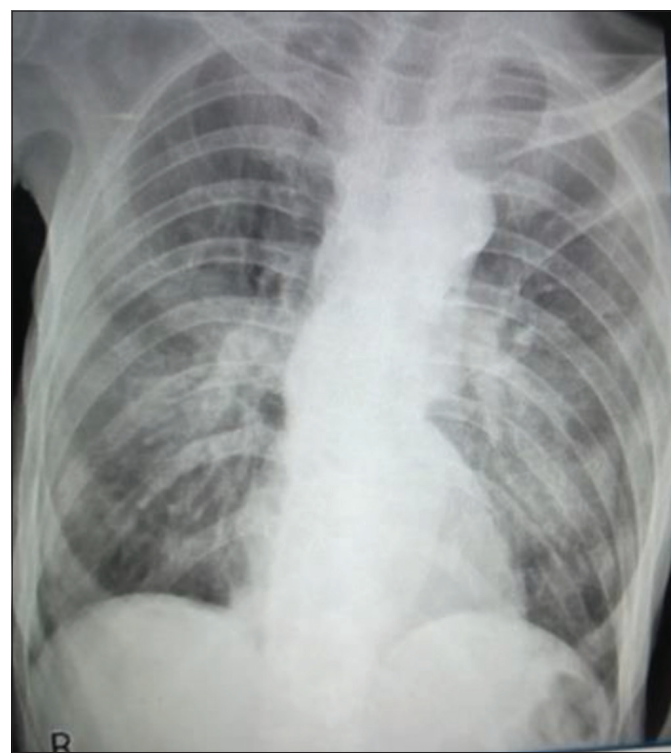

Figure 2: Plain chest X-ray

Prognosis of this elderly patient with no comorbidities, seven for the sequential organ failure assessment score, normal D-dimer, and high ferritin level indicate $<33.3 \%$ of mortality in the past $24 \mathrm{~h}$.

\section{Treatment and follow-up}

The patient admitted to an isolation room and got pharmacologic treatments. We gave six liters per minute Oxygen with a face mask. Fluid therapy included D5 $1 / 4 \mathrm{NS}$ : Aminofluid $=3: 1$, levofloxacin (750 mg q $48 \mathrm{~h}$ ), ceftriaxone ( $2 \mathrm{gr} \mathrm{q} 12 \mathrm{~h}$ for 5 days), dexamethasone (5 mg, q $12 \mathrm{~h}$ ), Avigan (1200 mg q $12 \mathrm{~h}$ loading dosage in the $1^{\text {st }}$ day, 600 mg q $12 \mathrm{~h}$ for 4 days), azithromycin (500 mg single dose for 4 days), Vitamin B1 $100 \mathrm{mg}$ PO single dose, Vitamin C $200 \mathrm{mg} \mathrm{q} 8 \mathrm{~h} \mathrm{IV}$, and Lantus 14 unit single-dose SC. In the $3^{\text {rd }}$ inpatient day, fever gets better; however, the patient still feels dyspnea and cannot obtain adequate eye contact: Respiratory rate $24 \mathrm{bpm}$, temperature $36.8 \mathrm{C}$, and $\mathrm{O}_{2}$ saturation $93 \%$. In the $5^{\text {th }}$ inpatient day, the patient had hypokalemia (2.79) then he got $25 \mathrm{mg}$ q intravenous calcium chloride in $500 \mathrm{ml}$ saline $0.9 \%$ in $24 \mathrm{~h}$, then switched to oral KSR until the calcium got normal value. In the $7^{\text {th }}$ inpatient day, dyspnea improved, no fever, and fully conscious, however, patient still complained pain over his shoulder, arm, and knee: Respiratory rate $18 \mathrm{bpm}$, temperature $36.3^{\circ} \mathrm{C}$, and $\mathrm{O}_{2}$ saturation $98 \%$. Then, in the $13^{\text {th }}$ inpatient day, dyspnea improved and no fever, however, patient still complains a pain over his shoulder and arm. Then, patient 
got a second result of nasopharynges and oropharynges swab for COVID-19, namely, positive. After 15 days of inpatient, the patient discharged from the hospital but get self-isolation with health protocol at home with better and stabile condition that indicates that patient has a good tolerability of the interventions and therapeutics during hospitalization. There are no adverse or unanticipated events during patient hospitalization. Follow-up is shown in Figure 3.

\section{Discussion}

COVID-19 is a disease that can cause severe pneumonia with a wide range of clinical manifestation, included neurological manifestation. Wan et al. presented a serial case with 135 patients and found out $88.9 \%$ suffer from fever and cough; fatigue and myalgia in $76 \%$; besides $32.5 \%$ with headache and only $13.3 \%$ with dyspnea [6]. The same symptoms found in our patient. Besides, various studies explained the neurologic manifestation in confirmed SARS-CoV-19 patients. One study focusing on the neurological presentation of SARS-CoV-2 which established by Mao, et al. in Wuhan, China, provided data that show $36 \%$ form 214 COVID-19 patients experience neurologic manifestation. Neurological manifestations variated that involved the central nervous system, peripheral nervous system, and symptoms or injury of skeletal muscles [7]. Muscle pain/myalgia showed a high incident rate beyond all neurological symptoms based in wild range studies. Huang et al. found that neurologic symptoms found in $44 \%$ of 41 patients [8]. Study bring up by Mao et al. reported that 10\% from 214 patient and study by Wan et al. showed that $32 \%$ of 135 patients suffer from myalgia.

The first PCR swab result of our patient come out positive, and after repeat, the examination after 10 days showed the same result. Muscles and joints symptoms were persistent from the onset of the first symptoms until the second swab PCR COVID-19.

Myalgia is a common symptom in patient with viral infection included novel COVID-19 and influenza. Myalgia indicates a general inflammation and cytokine response and could be an early symptom in $36 \%$ of patients with COVID-19. Myalgia due to COVID-19 usually lasts longer and more severe than myalgia caused by other viral infections. Myalgia and fatigue in COVID-19 patients have a longer duration than other viral infections and often not a response to conventional analgesic. Kucuk et al. when viral load decreased after treatment so reduce muscle pain. Besides the classic viral infection mechanism that caused myalgia, COVID-19 can be caused by musculoskeletal pain with different mechanisms [9]. In this case, the patient suffers from muscle and joint pain that not improved with analgesic and cause a sleep disturbance.

Symptoms of muscle injury often founded in COVID-10 infection. Musculoskeletal injury defined as patient deal with musculoskeletal pain and increased creatine kinase level to reach 200 U/L [10]. COVID-19

Table 1: Blood test result

\begin{tabular}{|c|c|c|c|c|c|c|c|c|c|c|c|c|c|c|}
\hline Date & WBC & $\mathrm{Ne}(\%)$ & Ly (\%) & RBC & $\mathrm{Hb}$ & HCT & PLT & NLR & Procal & C-reactive protein & BUN & Crea. & $\begin{array}{l}\text { SGOT (aspartate } \\
\text { aminotransferase) }\end{array}$ & $\begin{array}{l}\text { SGPT (alanine } \\
\text { aminotransferase) }\end{array}$ \\
\hline September 25, 2020 & 12.47 & 95.29 & 2.56 & 6.02 & 16.24 & 53.17 & 99 & 37.2 & 1.21 & 10.45 & 99.5 & 2.08 & 48.9 & 37.4 \\
\hline September 26, 2020 & 15.78 & 94.21 & 3.7 & 5.56 & 15.4 & 49.6 & 81.19 & 24.99 & & & 108.4 & 2.32 & & \\
\hline September 27, 2020 & & & & & & & & & & & 54.8 & 1.1 & & \\
\hline September 28, 2020 & 18.04 & 95.9 & 2.57 & 4.6 & 12.74 & 40.87 & 74.48 & 37.32 & 0.53 & & 45 & 0.74 & & \\
\hline September 29, 2020 & & & & & & & & & & & 32.2 & 0.60 & & \\
\hline October 01, 2020 & 14.4 & 96.4 & 1.66 & 4.53 & 12.7 & 38.5 & 96.5 & 58.09 & & & & & & \\
\hline October 06, 2020 & 11.65 & 92.6 & 3.03 & 4.75 & 13.35 & 40.7 & 177 & 21.25 & & & & & & \\
\hline
\end{tabular}

\begin{tabular}{|c|c|c|c|}
\hline $\begin{array}{l}\text { Admitted to hospital } \\
\text { - decrease in consciousness } 3 \text { hours before } \\
\text { admission } \\
\text { - fever for } 1 \text { week } 38.1 \mathrm{C} \\
\text { - muscle pain in shoulder, arm and knee } \\
\text { - Positive PCR Covid } 19 \\
\text { - Treatment: } \\
\text { - Ceftriaxone; Dexamethasone; Avigan; } \\
\text { Azithromycin; Vitamin B1; Vitamin C; } \\
\text { Lantus } 14 \text { unit }\end{array}$ & \multicolumn{3}{|l|}{$\begin{array}{l}\text { Inpatient Day } 5 \\
\text { hypokalemia } \\
(2.79) \text {, treatment } \\
\text { with } 25 \text { meq } \\
\text { intravenous } \\
\text { Kalium Chloride }\end{array}$} \\
\hline $\begin{array}{l}\text { Inpatient Day } 4 \\
\text { - fever gets better } \\
(36,8 \mathrm{C}) \\
\text { - dyspnea } \\
\text { (saturation 93\%) } \\
\text { - delirium }\end{array}$ & & $\begin{array}{l}\text { Inpatient Day } 7 \\
\text { - pain over his } \\
\text { shoulder, arm and } \\
\text { knee } \\
\text { - no dyspnea or } \\
\text { fever } \\
\text { - Fully conscious }\end{array}$ & $\begin{array}{l}\text { Inpatient day } 15 \\
\text { - discharged with } \\
\text { stabile and good } \\
\text { condition } \\
\text { - self isolation }\end{array}$ \\
\hline
\end{tabular}

Figure 3: Patient's timeline during hospitalization 
enters cell by engaged to angiotensin-converting enzyme-2 (ACE2) with low cytosol $\mathrm{pH}$ and causes infection in the respiratory system. ACE2 found in the brain, kidney, and vessels smooth muscle and skeletal muscle [11]. One article reported that lactate level increased due to massive cell damage during COVID-19 infection. In the case of hyperlactatemia, erythrocyte, which carries $\mathrm{O}_{2}$ to the tissues, destructed and this leads to tissue hypoxia. The virus spread through blood vessels or vascular endothelial and infected any tissue with ACE2 receptor as in the heart, brain, and muscles (Figure 4). To that, the musculoskeletal system infected and caused to rise creatinine kinase during the COVID-19 infection, which indicates muscle involved [10], [11]. Furthermore, pain in the extremities commonly reported as generalized fatigue without any of the other symptoms. SARS-CoV is known to be involved in cardiac muscle inflammation or myocardial inflammation, in contrast, COVID-19 patient often suffers from skeletal muscle pain (Figure 4). The cause of this pain could be due to the inflammation response of SARS-CoV-2 or direct damage to muscle cell [12].

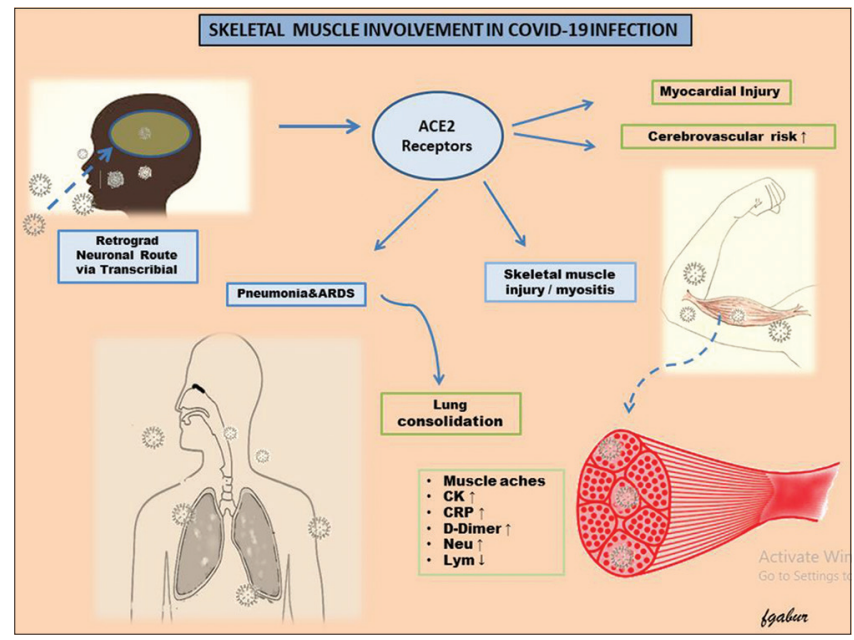

Figure 4: Skeletal muscle injury related to COVID-19 infection

Numerous studies provided that patient muscle injury has increased CRP level and D-dimer in addition to neutrophil level but with low lymphocyte level as compared with the COVID-19 patient without muscle injury. The presence of these abnormalities is an indication of increase inflammatory response and coagulopathy state [7], [9], [10]. Other than that, a study by Mao et al. found that patient with muscle damage experiences also multiorgan damage. There was hepatic abnormalities (increased lactate dehydrogenase, ALT, and AST) and kidney damage (increased blood Nitrogen urea, increased creatinine level) [7]. Severe COVID-19 group, patient with muscle injury undergoes decreased lymphocyte count and a serious hepatic injury (increased lactate dehydrogenase, ALT, and AST) and kidney injury (increased creatinine level) [7]. This is similar to our case, namely patient with increased CRP level, high D-dimer level, increased the neutrophil level, and diminished lymphocyte count, besides a liver disorder indicated by increase ALT and AST level, and kidney disorders showed by increased blood urea nitrogen and creatinine. Creatinine kinase test was not available in our facility. Cozzi et al. reported that a chest X-ray in COVID-19 variated. A total of 234 confirmed COVID-19 case reviewed, 135 patients show lung consolidation (57.7\%), 147 patients with ground-glass opacity $(62.8 \%), 55$ patients $(23,5 \%)$ with nodule, and a total of 156 patients $(66,6)$ with reticulonodular opacity [13]. Moreover, cases in Korea showed that patients with positive confirmed COVID-19, only $70 \%$ with consolidation [14]. Peripheral distribution (57.5\%) and basal area $(58,8 \%)$ are dominantly affected by COVID-19 infection. Bilateral lung involvement $(69,2)$ is most common in compare to unilateral lung involvement [12], [13]. Patient chest X-ray showed a specific image which is a lung consolidation with prominent bronchovascular marking.

Cases treated with Vitamin $\mathrm{C}$ showed an improvement in the immune system and shorten infection duration and optimal treatment results in respiratory infection as pneumonia [15]. Favipiravir (T-705) inhibits ribonucleic acid (RNA) polymerase, approved as COVID-19 therapy in China on February 15, 2020 [16]. Research shows that favipiravir is an RNA polymerase inhibitor; as a result, prevents viral RNA replication as in COVID-19 with minimal side effect. The initial dosage used in influenza in the adult is $1200 \mathrm{mg}$ favipiravir per oral, followed with $400 \mathrm{mg}$ as a maintenance dosage, given for 5 days [17]. In this case, favipiravir given for 4 days, which showed an improved in clinical features as fever got better and consciousness restored, despite dyspnea was persistent. Empiric antibiotics should be given to this with a suspect of bacterial infection, with specific symptoms and specific chest X-ray that indicates pneumonia. Increased neutrophil rate and lobular lung consolidation characterized as a bacterial infection. Several things are essential to refer to when initiating antibiotics, as start antibiotic with 4 $\mathrm{h}$ and do not wait for the microbiological test, give an antibiotic in the $1^{\text {st }} \mathrm{h}$ when sepsis is indicated and fill sepsis criteria [18]. Intravenous antibiotic indicated for severe pneumonia (example, signs and symptoms of sepsis in ventilator acquired pneumonia), or in case of antibiotic resistance, we can use antibiotic as follows: Co-amoxiclav: 1,2 gr q $8 \mathrm{~h}$ in combination with clarithromycin $500 \mathrm{mg} \mathrm{q} 12 \mathrm{~h} /$ day and cefuroxime: 750 mg q 8 h/day (increased to $750 \mathrm{mg} \mathrm{q} 6$ h/day or 1,5 q 8/day or q $6 \mathrm{~h} /$ day with severe infection). In severe pneumonia, if it does not fit the choice then replace it with levofloxacin: 500 mg 1 or 2 times/day. In our care, we followed guideline recommendation, the patient treated with Avigan (favipiravir) RNA polymerase inhibitor with initial dose $1200 \mathrm{mg}$ q $12 \mathrm{~h}$ followed by 4 days 600 mg q 12 h; we used azithromycin 500 mg once a day for 4 days, levofloxacin $750 \mathrm{mg}$ once a day, dexamethasone $5 \mathrm{mg} \mathrm{q} 12 \mathrm{~h}$, and Vitamin C $200 \mathrm{mg}$ intravenous q $8 \mathrm{~h}$. 


\section{Conclusion}

Numerous research and case study reported the neurologic manifestation in a patient with SARSCoV-2. In addition to neurologic manifestation, there is also respiratory and other organ manifestation. Neurological symptoms could be an early symptom in patient with COVID-19. Furthermore, it could be the only symptoms: Myalgia and general fatigue founded in high prevalence among patient with SARSCoV-2 infection. Recognition of symptoms in various manifestations is used for clinicians to be able to make a correct diagnosis so that they can provide optimal treatment.

\section{Ethics Approval and Consent to Participate}

The authors have obtained patient consent to participate in collecting data within this case report.

\section{Patient Perspective}

My illness started with fever and pain in all my joints and muscles. I started to lose my appetite and was always sleepy. I gave up my condition, I never thought I could get through all of this. But during the therapy, my condition is getting better day by day. And now, the important thing for me is that I recover and be able to be with my family.

\section{Patient Consent for Publication}

Written informed consent was obtained from the patient for publication of this case report and any accompanying images. A copy of the written consent is available for review by the editor of this journal.

\section{Acknowledgments}

We thank all the medical, nursing, and technical staffs from Isolation Ward of Sanglah Hospital for their dedicated care of our patient during the COVID-19 epidemic.

\section{Authors' Contributions}

AAAPL and MOG analyzed and interpreted the patient data regarding the neuromuscular disease related to pandemic viral infection. CT collected the patient data. All authors read and approved the final manuscript.

\section{References}

1. Xu T, Chen C, Zhu Z, Cui M, Chen C, Dai H, et al. Clinical features and dynamics of viral load in imported and nonimported patients with COVID-19. Int J Infect Dis. 2020;64:6871. https://doi.org/10.1016/j.ijid.2020.03.022

PMid:32179140

2. World Health Organization. Coronavirus Disease (COVID-19) Outbreak. Geneva: World Health Organization; 2019. Available from: $\quad$ https://www.who.int/emergencies/diseases/novelcoronavirus-2019. [Last accessed on 2020 Oct 07].

3. Abdullahi A, Candan SA, Abba MA, Bello AH, Alshehri MA Victor EA, et al. Neurological and musculoskeletal features of COVID-19: A systematic review and meta-analysis. Front Neurol. 2020;11:687. https://doi.org/10.3389/fneur.2020.00687 PMid:32676052

4. Cipollaro L, Giordano L, Padulo J, Oliva F, Maffulli N Musculoskeletal symptoms in SARS-CoV-2 (COVID-19) patients. J Orthop Surg Res. 2020;15(1):178. https://doi. org/10.1186/s13018-020-01702-w

PMid:32423471

5. Dewi VT, Laksmidewi AA, Sudiarini KA. Clinical manifestation and pathogenesis of nervous system involvement in severe acute respiratory syndrome Coronavirus-2 infection. Asian $\mathrm{J}$ Pharm Clin Res. 2020;13(10):23-8. https://doi.org/10.22159/ ajpcr.2020.v13i10.39006

6. Wan S, Xiang Y, Fang W, Zheng Y, Li B, Hu Y, et al. Clinical features and treatment of COVID-19 patients in Northeast Chongqing. J Med Virol. 2020;92(7):797-806. https://doi. org/10.1002/jmv.25783 PMid:32198776

7. Mao L, Jin H, Wang M, Hu Y, Chen S, He Q, et al. Neurologic manifestations of hospitalized patients with Coronavirus disease 2019 in Wuhan, China. JAMA Neurol. 2020;77(6):68390. https://doi.org/10.1001/jamaneurol.2020.1127 PMid:32275288

8. Huang $\mathrm{C}$, Wang $\mathrm{Y}, \mathrm{Li} \mathrm{X}$, et al. Clinical features of patients infected with 2019 novel coronavirus in Wuhan, China. Lancet. 2020;395(10223):497-506. doi:10.1016/ S0140-6736(20)30183-5

9. Kucuk A, Cure MC, Cure E. Can COVID-19 cause myalgia with a completely different mechanism? A hypothesis. Clin Rheumatol. 2020;39(7):2103-4. https://doi.org/10.1007/ s10067-020-05178-1 PMid:32458242

10. Sahin AR, Erdogan A, Agaoglu PM, Dineri Y, Cakirci AY, Senel ME, et al. 2019 novel Coronavirus (COVID-19) outbreak: A review of the current literature. Eurasian $\mathrm{J}$ Med Oncol. 2020;4(1):1-7.

11. Cure E, Cure MC. Comment on organ-protective effect of angiotensin-converting enzyme 2 and its effect on the prognosis 
of COVID-19. J Med Virol. 2020;92(9):1423-4. https://doi. org/10.1002/jmv. 25848

PMid:32266994

12. Hamming I, Timens W, Bulthuis ML, Lely AT, Navis G, van Goor $\mathrm{H}$. Tissue distribution of ACE2 protein, the functional receptor for SARS coronavirus. A first step in understanding SARS pathogenesis. J Pathol. 2004;203(2):631-7. https://doi. org/10.1002/path.1570

PMid: 15141377

13. Cozzi D, Albanesi M, Cavigli E, Moroni C, Bindi A, Luvara S, et al. Chest X-ray in new Coronavirus disease 2019 (COVID19) infection: Findings and correlation with clinical outcome. Radiol Med. 2020;125(8):730-7. https://doi.org/10.1007/ s11547-020-01232-9

PMid:32519256

14. Cleverley J, Piper J, Jones MM. The role of chest radiography in confirming COVID-19 pneumonia. BMJ. 2020;370:m2426. https://doi.org/10.1136/bmj.m2426

PMid:32675083

15. Carr AC, Maggini S. Vitamin $C$ and immune function. Nutrients. 2017;9(11):1211.

PMid:29099763

16. Dong L, Hu S, Gao J. Discovering drugs to treat Coronavirus disease 2019 (COVID-19). Drug Discov Ther. 2020;14(1):58-60. https://doi.org/10.5582/ddt.2020.01012

PMid:32147628

17. Cai Q, Yang M, Liu D, Chen J, Shu D, Xia J, et al. Experimental treatment with favipiravir for COVID-19: An open-label control study. Engineering (Beijing). 2020;6(10):1192-8.

PMid:32346491

18. NICE. COVID-19 Rapid Guideline: Antibiotics for Pneumonia in Adults in Hospital; 2020. Available from: https://www.nice.org. uk/terms-and-conditions\#notice-ofrights. [Last accessed on 2020 Oct 07] 